\title{
Identification of Bovine Growth Hormone (BGH) Gene Polymorphism Using PCR-RFLP Method in Buffalo Bulls
}

\author{
M. I. S. Hazlan Shah ${ }^{1}$, M. S. Salisi ${ }^{1^{\star}}$, H. Wahid ${ }^{2}$, M. S. Yahaya ${ }^{2,3}$, Y. Rosnina ${ }^{2}$, \\ M. Zamri-Saad ${ }^{4}$, M. Ariff Omar ${ }^{1}$, A. Punimin ${ }^{5}$, H. A. Hassim ${ }^{1}$, \\ Hafandi Ahmad ${ }^{1}$ and M. I. Nur Mahiza ${ }^{6}$ \\ ${ }^{1}$ Department of Preclinical Sciences, Universiti Putra Malaysia, 43400 Serdang, Malaysia. \\ ${ }^{2}$ Department of Veterinary Clinical Studies, Universiti Putra Malaysia, 43400 Serdang, Malaysia. \\ ${ }^{3}$ Faculty of Veterinary Medicine, Usmanu Danfodiyo University, Sokoto, Nigeria. \\ ${ }^{4}$ Research Center for Ruminant Diseases, Universiti Putra Malaysia, 43400 Serdang, Malaysia. \\ ${ }^{5}$ Faculty of Sustainable Agriculture, Universiti Malaysia Sabah, Locked Bag No 3, 90509, Sandakan, \\ Sabah, Malaysia. \\ ${ }^{6}$ Department of Veterinary Pathology and Microbiology, Universiti Putra Malaysia, 43400 Serdang, \\ Malaysia.
}

Authors' contributions

This work was carried out in collaboration among all authors. All authors read and approved the final manuscript.

Article Information

DOI: 10.9734/ARRB/2019/v33i130111

Editor(s):

(1) Prof. Xiao-Xin Yan, Department of Anatomy and Neurobiology, Central South University Xiangya, School of Medicine, Changsha, Hunan, China.

(1) Sandra Elizabeth Perez, Argentina. (2) Wafaa Abd El-Ghany Abd El-Ghany, Cairo University, Egypt. Complete Peer review History: http://www.sdiarticle3.com/review-history/51291

Original Research Article

Received 27 June 2019

Accepted 31 August 2019

Published 14 September 2019

\section{ABSTRACT}

Growth Hormone $(\mathrm{GH})$ is a single polypeptide chain synthesised and secreted from anterior pituitary gland by somatroph cells. The product of $\mathrm{GH}$ gene hastens metabolism and promotes the growth of many organs and tissues especially bone, muscle and visceral organs. It also regulates growth, mammary gland development and lactation. Polymorphism in this gene is associated with increase in growth and development of many tissues in the body. 


\begin{abstract}
Aim: The objective of this study was to investigate the polymorphism of bovine growth hormone (bGH) gene in buffalo bulls (Bubalus bubalis) using the PCR-RFLP (polymerase chain reactionrestriction fragment length polymorphism) technique.

Design: Genomic DNA was extracted from a total of 10 bulls, consisting of Murrah - Swamp crossbred and pure Swamp buffalo bulls. A-The 446 segment of the bGH gene was amplified. The DNA amplicons were detected in $2 \%$ agarose gel following 45 minutes of electrophoresis. They were thereafter digesting with Alul endonuclease restriction enzyme, and the digested DNA were detected in $2 \%$ agarose gel following electrophoresis for about 45 minutes in all samples

Results: Similar bands of approximately 300 and 146-bp each, with no variation, were detected in $2 \%$ agarose gel following electrophoresis in all the animals tested.

Conclusion: Based on the Alu1 digestion result, all samples produced the same allele of the gene, with no polymorphism detected.
\end{abstract}

Keywords: Buffalo; Bovine Growth Hormone (BGH); PCR-RFLP; polymorphism.

\section{INTRODUCTION}

Generally, buffaloes provide mechanical draught power, meat and milk for human consumption. In Malaysia, $60 \%$ of the buffaloes are mostly concentrated in the rice growing states of Kelantan, Terengganu, Kedah and Pahang. This is mainly due to their capability to be used as draught power in agriculture.

Buffalo population has seen a steady increase, it stood at 177.247 million in 2012 [1]. According to [2], buffaloes are spread through 42 countries, with Asian buffalo population representing 97\% of the world total. The rest of world therefore accounts for only $3 \%$. Currently, one of the focus of studies in the field of animal genetics is the identification of genes with important influence on the expression of quantitative traits. Polymorphisms in these genes, which are also referred as candidate genes, plays an important role in animal selection and breeding. One of these genes, which is potentially polymorphic with a lot of selection benefit is the growth hormone gene [3]. Several studies have indicated the association between polymorphism of the bovine growth hormone $(\mathrm{GH})$ gene and production traits although with divergent results in some cases [4-6]. Growth hormone is a polypeptide hormone secreted by somatroph cells from the anterior pituitary glands [7]. GH gene has been assigned to 19q26q-ter position in the bovine chromosome [8]. Polymorphism in the $\mathrm{GH}$ gene has been detected in cattle after digestion with Alu restriction endonuclease [911]. Two alleles have been identified following the use of this enzyme, the $L$ and the $V$ alleles. Animals with genotype LL were reported to be superior, in terms of milk production and other production traits, to those carrying the LV genotype [9]. The buffalo ( $\mathrm{B}$ b) growth hormone gene is similar to that of cattle $(B t / i)$. The size of $\mathrm{GH}$ gene is approximately 1798 bp [12], consisting of five exons and four introns, with the mRNA being about 654 bp in length (Fig. 1). GH gene of cattle and buffalo having $98.6 \%$ sequence homology [12]. However, despite its potentials in animal breeding and selection, the amount of studies regarding $\mathrm{GH}$ gene polymorphism are scanty [13].

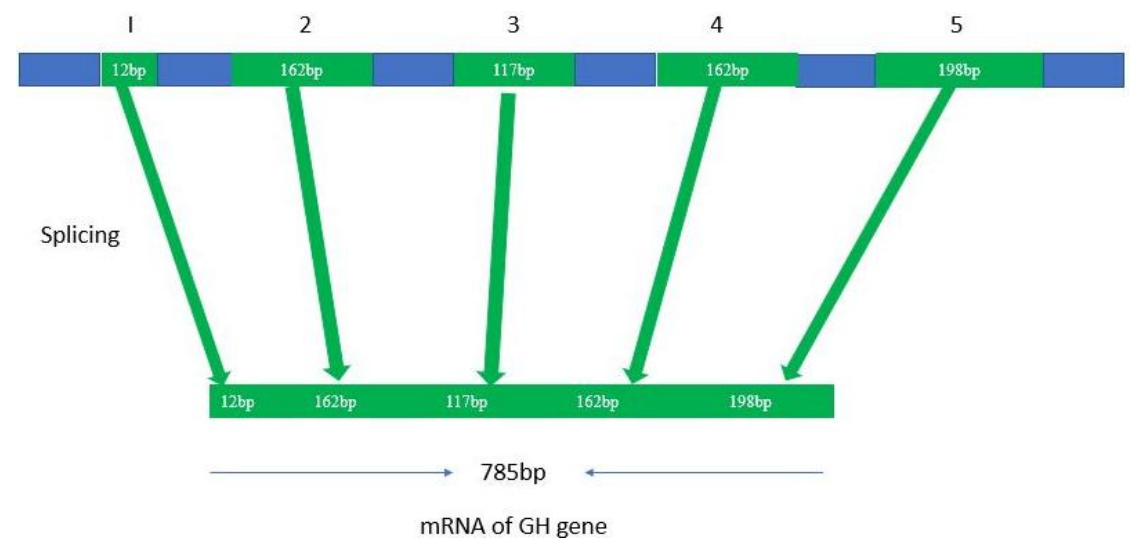

Fig. 1. Length of bovine $\mathrm{GH}$ gene 1793 bp with five exons and four introns 


\section{MATERIALS AND METHODS}

\subsection{Sample Collection and Storage}

Blood samples were taken from 10 buffalo bulls maintained at the Buffalo Breeding and Research Centre, Department of Veterinary Services and Animal Industry, Telupid, Sabah. Ten millilitres of venous blood were collected from the jugular vein of each animal in a sterile $50 \mathrm{ml}$ polypropylene vial containing $0.5 \mathrm{M}$ EDTA as anti-coagulant. The samples were subjected to analysis for bGH genomic DNA using PCR-RFLP (polymerase chain reaction - restriction fragment length polymorphism) method. The tubes containing EDTA were centrifuged at 3,000 rpm for 5 minutes and the buffy coats were obtained from the blood. The buffy coats were transferred to $1.5 \mathrm{ml}$ microcentrifuge tube and stored at -20 ${ }^{\circ} \mathrm{C}$ until further processing. Genomic DNA was extracted from the samples with GeneJET TM GenomicDNA Purification Kit (Thermo Scientific, USA) according to manufacturer's protocol.

\subsection{Genomic DNA Extraction}

A total of $200 \mu$ l blood sample (buffy coat) was lysed by adding $400 \mu \mathrm{l}$ Lysis Buffer Solution and $20 \mu \mathrm{l}$ Proteinase $\mathrm{K}(10 \mathrm{mg} / \mathrm{ml})$, which was then incubated at $56^{\circ} \mathrm{C}$ for 10 minutes. After incubation, $200 \mu \mathrm{l}$ of $96 \%$ absolute ethanol was added and the resulting mixture was applied into the GeneJET'тм Purification Column. The column was centrifuged at $6000 \mathrm{x} \mathrm{g}$ for 1 minute. DNA purification was conducted using spin column by adding $500 \mu \mathrm{l}$ Wash Buffer I solution followed by centrifugation at $8000 \mathrm{x} \mathrm{g}$ for 1 minute. After the supernatants (flow-through) were discarded, the DNA was washed again with $500 \mu$ of Wash Buffer II and centrifuged at $13000 x \mathrm{~g}$ for 3 mins.
After the supernatants (flow-through) were discarded, the DNA was eluted with $200 \mu \mathrm{l}$ Elution Buffer and centrifuged at $8000 \times \mathrm{xg}$ for 1 min. The flow-through elution was collected and stored at $-20^{\circ} \mathrm{C}$. DNA quality, quantity and purity, were assessed using a Nanodrop spectrometer (DNA TECH, UCDAVIS GENOME CENTER); 1 ul of each sample was placed on the lower optical pedestal, the lower lever arm was closed and the sample read via a computer application. The concentration (ng/ul) and the purity at 260/280 and 260/230 were recorded.

\subsection{Polymerase Chain Reaction (PCR)}

Amplification of bovine growth hormone $(\mathrm{bGH})$ gene fragments was done using polymerase chain reaction (PCR) method (Bio-Rad Thermal Cyclers). GH2 forward (5'-CGG ACC GTG TCT ATG AGA AGC TGA AG-3') and reverse (5'-GTT CTT GAG CAG CGC GTC GTC A-3') primer sequences published by Reis et al. (2001) and Balogh et al. (2009) were used to amplify the $436 \mathrm{bp}$ fragments of the $\mathrm{GH}$ gene. The PCR protocol was performed using Taq PCR Master Mix Kit (QIAGEN Germany) in a $25 \mu$ reaction mixture containing $12.5 \mu \mathrm{l} \mathrm{PCR}$ master mix (250 units Hot Star Taq DNA Polymerase, PCR Buffer with $3 \mathrm{mM} \mathrm{MgCl} 2$, and $400 \mu \mathrm{M}$ of each dNTP), 5 $\mu \mathrm{l}$ template genomic DNA, $0.5 \mu \mathrm{l}$ of each $\mathrm{GH} 2$ forward and reverse primers, and $6.5 \mu \mathrm{l}$ nuclease-free water. The PCR reactions were run at initial denaturation temperature at $95^{\circ} \mathrm{C}$ for 3 minutes, followed by 35 cycles of denaturation at $95^{\circ} \mathrm{C}$ for 1 minute, annealing at $55^{\circ} \mathrm{C}$ for 1 minute, followed by extension at $72^{\circ} \mathrm{C}$ for 1 minute and one cycle of final extension at $72^{\circ} \mathrm{C}$ for 12 minutes, which ended with infinity duration at $4^{\circ} \mathrm{C}$.

Table 1. Growth hormone DNA sequences and their corresponding Gen Bank accession numbers

\begin{tabular}{lll}
\hline S/NO & Sequence ID & Accession number \\
\hline 1 & Banklt2060151 UPM3926 & MG450554 \\
2 & Banklt2060151 UPMTBN1 & MG450555 \\
3 & Banklt2060151 UPMTBN2 & MG450556 \\
4 & Banklt2060151 UPM1SAWAH & MG450557 \\
5 & Banklt2060151 UPM2SAWAH & MG450558 \\
6 & Banklt2060151 UPM3SAWAH & MG450559 \\
7 & Banklt2060151 UPM3898 & MG450560 \\
8 & Banklt2060151 UPM839 & MG450561 \\
9 & Banklt2060151 UPM830 & MG450562 \\
10 & Banklt2060151 UPMTBN3 & MG450563 \\
\hline
\end{tabular}




\subsection{Gel Electrophoresis and Documen- tation}

The PCR products were electrophoresed on $2 \%$ agarose gel stained with Ethidium Bromide at a constant voltage (90V) for 45 minutes. The result was visualised under U.V light using Gel Doc ${ }^{\mathrm{TM}}$ system.

\subsection{Restriction Fragment Length Poly- morphism (PCR-RFLP)}

The PCR products for the tested fragments were digested with the restriction endonuclease enzyme, Alul. The restriction mixture for each sample was prepared into new microcentrifuge tubes by adding $17 \mu$ l of nuclease-free water followed by $2 \mu \mathrm{l}$ of $10 \mathrm{X}$ FastDigest Green Buffer in each sample, $10 \mu \mathrm{l}$ of the DNA (PCR product) and lastly $1 \mu \mathrm{l}$ of FastDigest enzyme containing Alul. The restriction mixture was then gently mixed and spun down using vortex for a few seconds and incubated at $37^{\circ} \mathrm{C}$ in a water bath for 15 minutes. Then, the enzyme was inactivated by further heating at $65^{\circ} \mathrm{C}$ for 5 minutes. The digested PCR products were electrophoresed on $2 \%$ agarose gel at $90 \mathrm{~V}$ for 45 minutes. Gel was stained by ethidium bromide and visualised on UV transiluminator and finally documented in Gel Doc system.

\section{RESULTS AND DISCUSSION}

\subsection{Amplification of bGH Gene Using GH2 Primers}

The PCR product of bGH gene with a fragment length size of 436 bp was amplified with primer $\mathrm{GH} 2$, which was electrophoresed on $2 \%$ agarose gel stained with ethidium bromide at a constant $90 \mathrm{~V}$ for 45 minutes. Lane M showed DNA ladder (100-1000). The amplicons were visualised under U.V transilluminator light using Gel Doc ${ }^{\mathrm{TM}}$ system (Fig. 2).

The PCR products were sequenced using Sanger's method. The complete sequence of all $10 \mathrm{bGH}$ genes was analysed using MEGA version 10 and BioEdit software. The sequences were later submitted to the GenBank database and Accession Numbers were obtained (Table 1)

\subsection{Digestion of PCR Product of bGH Gene with Alul Enzyme}

The digestion of PCR products of $\mathrm{bGH}$ gene with the size of 295- and 100- bp was conducted using Alul endonuclease restriction enzyme. The product was electrophoresed on $2 \%$ agarose gel stained with 10X Fast Digest Green Buffer at constant $90 \mathrm{~V}$ for 45 minutes. Lane M displayed DNA ladder (100-1000). PCR was visualised under U.V light usingGel Doc ${ }^{\mathrm{TM}}$ system (Fig. 2).

\subsection{Determination and Amplification of bGH Gene Fragments}

In wells 2 to 10 , similar bands were observed on $2 \%$ agarose gel under the view of UV transilluminator light. The fragments' size/length produced ranged between $400-$ and $500 \mathrm{bp}$. In order to confirm the DNA of bovine growth hormone $(\mathrm{bGH})$ gene fragments' size/length, semi-log graph was used and plotted the axis using GraphPad PRISM®7. The bGH gene fragments' size/length was determined by plotting the x-axis(distance migrated) and y-axis (inverted log base pair) in GraphPad PRISM®7 and 436-bp was observed when compared with DNA ladder on Lane $M$. Fragments length amplification product was done by matching the primers set alignment with bGH gene sequence. Previous studies on bGH gene polymorphisms in buffaloes (Bubalus bubalis) by Balogh et al. (2009) and Andreas et al. (2010) showed the fragments length of bGH gene of $428 \mathrm{bp}$ and $432 \mathrm{bp}$, respectively. This result is different from that of other studies [13]. However, any of the studies demonstrated the 436 bp $\mathrm{GH}$ fragment as in this study. Eventhough the base pair (bp) produced was different, it matched with $\mathrm{GH} 2$ primer $(\mathrm{F}=$ 5'CGGACCGTGTCTATGAGAAGCTGAAG - 3' and $\mathrm{R}=$ 5'-GTTCTTGAGCAGCGCGTCGTCA 3 ' [14] used in this study producing $436 \mathrm{bp}$ on $2 \%$ agarose gel electrophoresis. Primer sequences used by [14] have been frequently used in determining $\mathrm{GH}$ gene sequence of the DNA fragments length. The primers were rechecked through BLAST® NCBI (https://blast.ncbi.nlm.nih.gov/Blast.cgi) for confirmation. All the amplicons showed very high similarity with those on the GenBank. Therefore, it can be assured that the bands produced on $2 \%$ agarose gel electrophoresis in this work were those of $\mathrm{GH}$ gene with 436 bp fragment length.

\subsection{PCR-RFLP Analysis of bGH Gene Polymorphisms}

Determination of bovine growth hormone $(\mathrm{bGH})$ gene polymorphism in thisst udy was done using PCR-RFLP method. This method used endonuclease restriction enzyme, Alul, which 
has a cutting site at 5' AG|CT 3' and 3'TC|GA 5'. Based on DNA sequences of bGH genes amplified segment, there were two Alul cutting sites that produced fragments of 295 and $100-b p$ long in the presence of the restriction site at position $100^{\wedge} 101 \quad(\mathrm{AG} \wedge \mathrm{CT})$. This result is supported by that of [11] in their studies on Indian and Egyptian buffaloes as well as cattle (Fig. 3).

The Alul restriction endonuclease enzyme has a specific target on PCR fragments of the $\mathrm{bGH}$ gene containing exon 5 and the alleles found were designated with $L$ and $V$ (Fig. 4). The $L$ allele is responsible for the formation of bGH with an amino acid residue of leucine at position 127, whereas the $V$ allele is responsible for an alternative form with a valine residue at the same position [15]. [16] reported a polymorphic site for Alul restriction endonuclease localised in the exon 5 in bovine $\mathrm{GH}$ gene and characterised by the substitution of cytosine $[\mathrm{C}]$ for guanine $[\mathrm{G}]$ at position 2,141 causing an amino acid change from leucine to valine at residue 127 . The presence of homozygous LL genotype suggests that the Alul restriction endonuclease enzyme

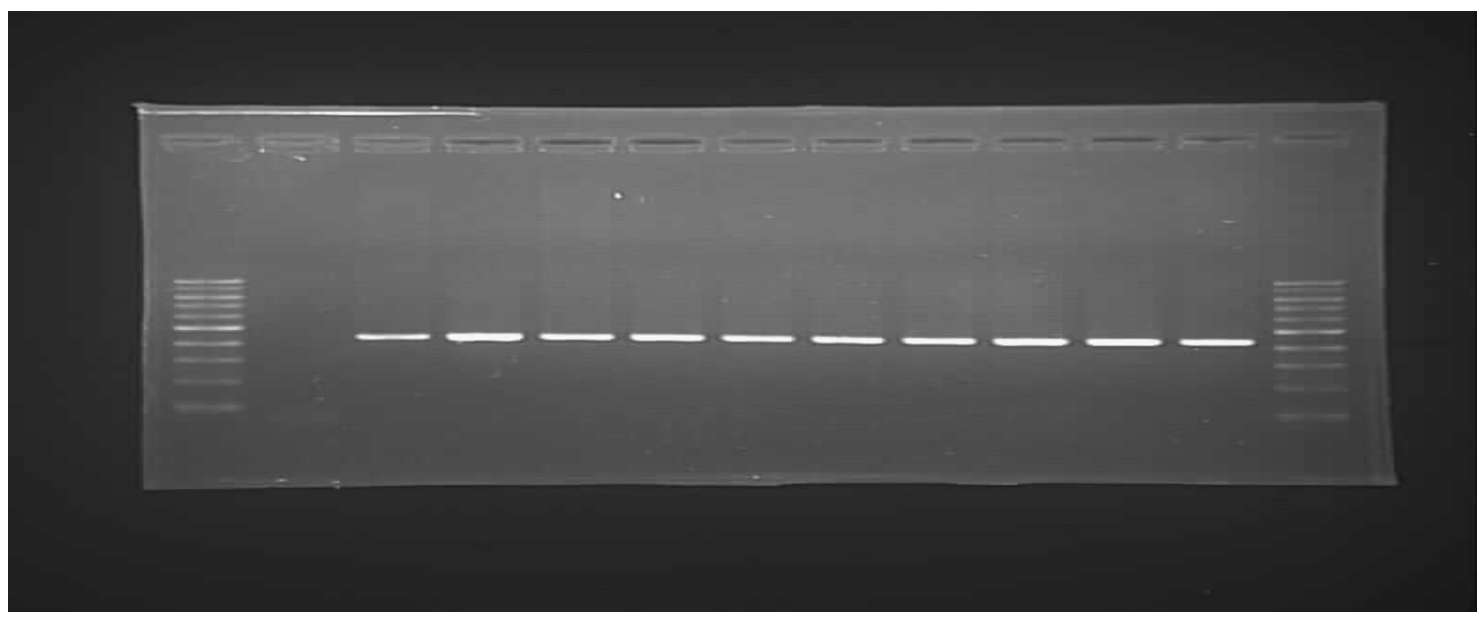

Fig. 2. The PCR products of bGH gene with size of $446 \mathrm{bp}$, amplified using GH2 primer. Lane M and 12 DNA ladder (100-1000). Lane 1 is negative control. Lane 2-11 display the PCR product for each DNA sample

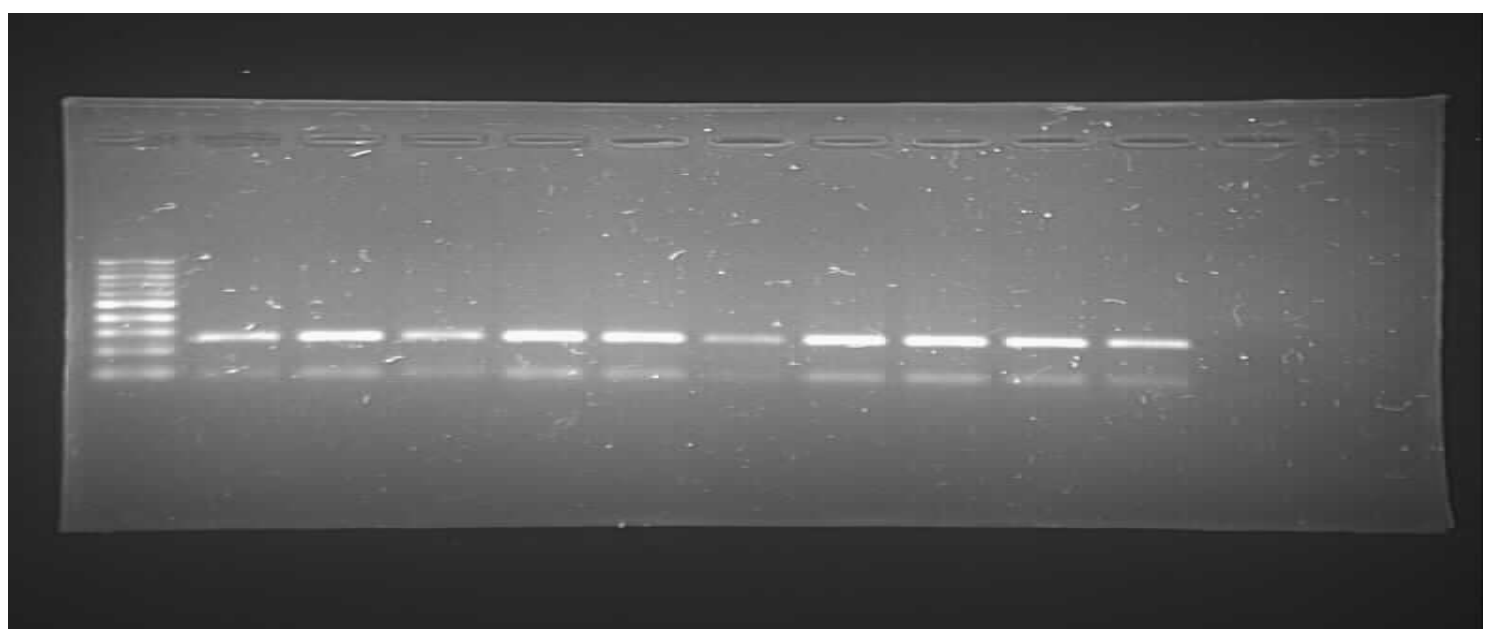

Fig. 3. The digested PCR products with Alul restriction enzyme of bGH with size of 295- and 100-bp. Lane M shows DNA ladder (100-1000). Lane 1-11: PCR products with Alul restriction enzyme. Lane 12: Negative control 


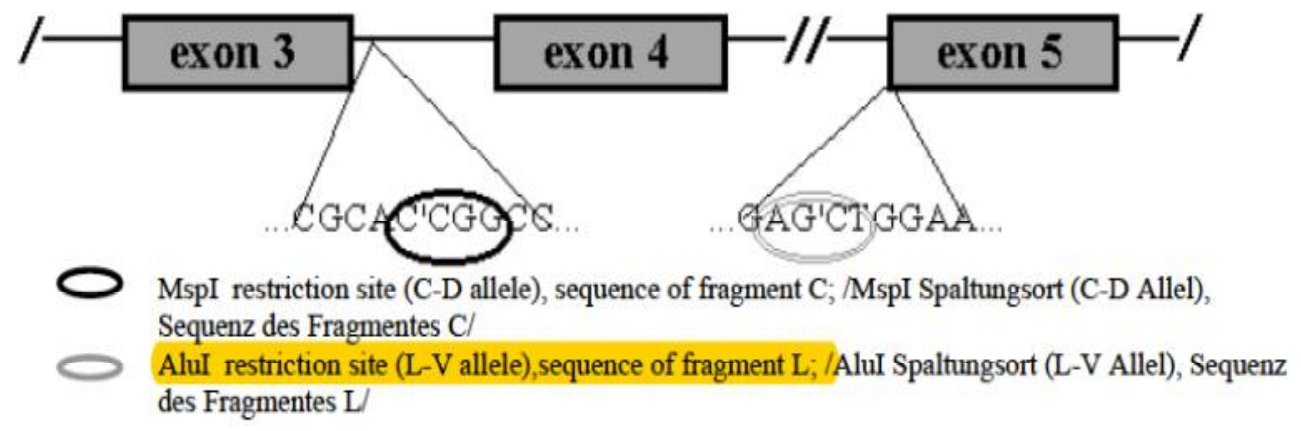

Fig. 4. The Alul RE enzyme specifically targets exon 5 containing cutting site of AG|CT

recognised the sequence on both helixes of DNA and cut at the two restriction sites, $A G \mid C T$. Besides, presence of recessive $\mathrm{V}$ allele on DNA fragment indicated no restriction site recognised by the Alul restriction endonuclease. However, in contrast, this result is in partial disagreement with that by [17] with the presence of VV genotype through their study on $\mathrm{GH} /$ Alul gene polymorphisms in Slovak cattle, which might be due to product size that was considered large and has more than one restriction site for the same enzyme. Thus, to obtain more accuracy, another primer was used to shorten the PCR product giving only one site for the Alul enzyme $\mathrm{GH} 2$. This showed that each well had a similar genotype. All buffaloes investigated in this study were genotyped as LL where all tested buffalo DNA amplified fragments were digested with Alul endonuclease and gave two digested fragments at 295- and 100- bp due to the presence of a restriction site at position $100^{\wedge} 101$ (AG^CT). According to [11], the $\mathrm{L}$ allele indicates the presence of restriction site while its absence is assigned as allele $\mathrm{V}$. In $\mathrm{L}$ allele, the restriction site contains nucleotide $\mathrm{C}$, while a transition with $\mathrm{G}$ at the same site indicates the absence of Alul restriction site. The presence of nucleotide $C$ in the total length of amino acid in growth hormone (191) occurs in position 127of the polypeptide [18] According to [16], the distribution of bGH genotypes and alleles contains the already known phenomenon where the $L$ allele is predominant in dairy cattle, whereas the $\mathrm{V}$ allele occurs more frequently in beef cattle. The presence of nucleotide (C) at triplet codon encodes the amino acid Leucine, while nucleotide $G$ encodes the amino acid Valine. This Leucine/Valine substitution indicates polymorphism. In this study, no polymorphism was identified. The values of the fragments' length produced were calculated using the same method as bGH gene fragment length base pair values by plotting a semi-log graph in Graph Pad
PRISM®7. By observing two bands produced with the same fragment length size, it can be deduced that these DNA carried the same genotypes, thus supporting the statement above. There are no other studies done on the polymorphisms of the same fragment length; however, a study done by [14] demonstrated $\mathrm{GH}$ gene with $211 \mathrm{bp}$ that produced two separate bands with same values of fragment length at 159- and 52-bp, respectively. Therefore, buffalo bulls used in this study were having monomorphic gene loci and as a result, no polymorphism was identified in the10 samples of buffalo bulls.

\section{CONCLUSION}

In conclusion, all buffalo bulls investigated in this study were genotyped as LL and the diversity of $\mathrm{GH}$ | Alul was very low, showing no polymorphisms in their bGH genes. This could have resulted from the low diversity of bGH genes among the buffalo bulls due to limited number of males in the farm and high inbreeding frequency. Therefore, for future study, it is recommended to use more buffalo bulls from different locations and farms to increase gene diversity in the samples to be examined for gene polymorphism. For the farms involved in this study, itis highly recommended to increase the number of breeding bulls by purchasing new bulls from other locations or breeding farms to increase genetic diversity and to avoid inbreeding practice. The use of different restriction endonuclease enzymes in PCR method could be considered since the genes may be having different sites of polymorphism. Therefore, the potential of bGH gene as candidate gene for genetic-marker to be used in breeding programme in buffaloes could only be considered once the presence of bovine growth hormone $(\mathrm{bGH})$ gene polymorphism can be detected. 


\section{ETHICAL APPROVAL}

All authors hereby declare that "Principles of laboratory animal care" (NIH publication No. 8523, revised 1985) were followed, as well as specific national laws where applicable. All experiments have been examined and approved by the appropriate ethics committee

\section{COMPETING INTERESTS}

Authors have declared that no competing interests exist.

\section{REFERENCES}

1. FAO. The state of food and agriculture; 2012.

2. Habib MR, Haque MN, Rahman A, Aftabuzzaman M, Ali MM, Shahjahan M. Dairy buffalo production scenario in Bangladesh: A review. Asian J Med Biol Res. 2017;3(3):305-16.

3. Dolmatova II, II'iasov IG. Association of cattle growth hormone gene polymorphism with milk productivity. Genetika [Internet]. 2011;47(6):814-20.

[Cited 2019 Jul 16]

Available:http://www.ncbi.nlm.nih.gov/pub $\mathrm{med} / 21866862$

4. Arango J, Echeverri J, Lopez A. Association of the bovine growth hormone gene with Holstein cattle reproductive parameters Asociación del gen de la hormona de crecimiento bovino con. Rev MVZ Cordoba. 2014;19(3):4249-58.

5. Amiri $S$, Jemmali $B$, Amine Ferchichi $M$, Jeljeli $H$, Boulbaba $R$, Ben Gara A. Assessment of growth hormone gene polymorphism effects on reproductive traits in Holstein dairy cattle in Tunisia. Arch Anim Breed. 2018;61(4):481-9.

6. Hernández $\mathrm{N}$, Martínez-González JC, Parra-Bracamonte GM, Sifuentes-Rincón AM, López-Villalobos $\mathrm{N}$, Morris ST, et al. Association of polymorphisms in growth hormone and leptin candidate genes with live weight traits of Brahman cattle. Genet Mol Res. 2016;15(3).

7. Ayuk J, Sheppard MC. Growth hormone and its disorders. Postgrad Med J [Internet]. 2006;82(963):24-30.

[Cited 2019 Jul 16]

Available:http://www.ncbi.nlm.nih.gov/pub med/16397076

8. Hediger $\mathrm{R}$, Johnson SE, Barendse $\mathrm{W}$, Drinkwater RD, Moore SS, Hetzel J.
Assignment of the growth hormone gene locus to 19q26-qter in cattle and to 11q25qter in sheep by in situ hybridization. Genomics [Internet]. 1990;8(1):171-4.

[Cited 2019 Jul 16]

Available:https://linkinghub.elsevier.com/re trieve/pii/088875439090241L

9. Pal A, Chakravarty AK, Bhattacharya T, Joshi BK, Sharma A. Detection of polymorphism of growth hormone gene for the analysis of relationship between allele type and growth traits in karan fries cattle. Asian-Australasian J Anim Sci. 2004;17.

10. Akçay A, Akyüz B, Bayram D. Determination of the alui polymorphism effect of bovine growth hormone gene on carcass traits in zavot cattle with analysis of covariance. Turkish J Vet Anim Sci. 2015; 39(1):16-22.

11. Biswas TK, Bhattacharya TK, Narayan AD, Badola S, Kumar P, Sharma A. Growth hormone gene polymorphism and its effect on birth weight in cattle and buffalo. AsianAustralasian J Anim Sci [Internet]. 2003; 16(4):494-7.

[Cited 2019 Jul 16]

Available:http://ajas.info/journal/view.php? doi=10.5713/ajas.2003.494

12. Verma S, Ghorpade A, Tiwari G, Das P, Garg LC. cDNA cloning and sequence analysis of bubaline growth hormone. DNA Seq [Internet]. 1999;10(2):101-3.

[Cited 2019 Jul 16]

Available:http://www.ncbi.nlm.nih.gov/pub med/10376211

13. Hussain DA, Ghareeb AM, Salo WH. Evaluation of dna polymorphism in bovine growth hormone gene by pcr-rflp method. Internarional J Sci Nat. 2014;5(3):40711.

14. Balogh $\mathrm{O}$, Kovács $\mathrm{K}$, Kulcsár $\mathrm{M}$, Gáspárdy $A$, Zsolnai $A$, Kátai $L$, et al. Alul polymorphism of the bovine growth hormone $(\mathrm{GH})$ gene, resumption of ovarian cyclicity, milk production and loss of body condition at the onset of lactation in dairy cows. Theriogenology [Internet]. 2009; 71(4):553-9.

[Cited 2019 Jul 16]

Available:http://www.ncbi.nlm.nih.gov/pub $\mathrm{med} / 19111333$

15. Fedota OM, Lysenko NG, Ruban SY, Kolisnyk OI, Goraychuk IV. The effects of polymorphisms in growth hormone and growth hormone receptor genes on production and reproduction traits in Aberdeen-Angus cattle (Bos taurus L., 
1758). Cytol Genet [Internet]. 2017;51(5): 352-60.

[Cited 2019 Jul 16]

Available:http://link.springer.com/10.3103/ S0095452717050024

16. Lucy MC, Hauser SD, Lucy MC, Hauser SD, Eppard PJ, Krivi GG CR. Genetic polymorphism within the bovine somatotropin (bST) gene detected by polymerase chain reaction and endonuclease digestion. J Dairy Sci. 1991;74(Suppl 1):284.
17. Moravcikova N, Trakovicka A, Hazuchova $\mathrm{E}$. The association of bovine growth hormone gene polymorphism with milk performance traits in slovak spotted cows. Anim Sci Biotechnol. 2012;45(1):206-10.

18. Tety Hartatik, Slamet Diah Volkandari MPR. S. Polymorphism leu/val of growth hormone gene identified from limousin cross local cattle in Indonesia. In: The $3^{\text {rd }}$ International Conference on Sustainable Future for Human Security SUSTAIN. Elsevier B.V. 2012;105-8.

(c) 2019 Shah et al.; This is an Open Access article distributed under the terms of the Creative Commons Attribution License (http://creativecommons.org/licenses/by/4.0), which permits unrestricted use, distribution, and reproduction in any medium, provided the original work is properly cited.

Peer-review history:

The peer review history for this paper can be accessed here: http://www.sdiarticle3.com/review-history/51291 